\title{
APPLICATION OF THE METHOD OF ARTIFICIAL INSEMINATION OF BREEDING STOCK COWS
}

\section{СИЫРЛАРДЫҢ АНАЛЫҚ БАСЫН ҚОЛДАН ҰРЫҚТАНДЫРУ ӘДІСІН ҚОЛДАНУ

\author{
ПРИМЕНЕНИЕ МЕТОДА ИСКУССТВЕННОГО ОСЕМЕНЕНИЯ \\ МАТОЧНОГО ПОГОЛОВЬЯ КОРОВ
}

\author{
M.B. KALMAGAMBETOV*1 \\ C.Agr.Sc., Associated Professor \\ A.N. KARABAYEVA ${ }^{2}$ \\ Master of Agriculture \\ ${ }^{1}$ Kazakh Scientific Research Institute of Animal Husbandry and Forage Production, \\ Almaty, Kazakhstan \\ ${ }^{2}$ Kazakh Research Institute of Economy of Agro-Industrial Complex and \\ Rural Development, Almaty, Kazakhstan \\ *mbaitugel@mail.ru \\ М.Б. ҚАЛМАГАМБЕТОВ \\ а.-щ.Ғ.К., доцент \\ A.H. ҚАРАБАEBA ${ }^{2}$ \\ ауыл шаруашылығы магистрі \\ ${ }^{1}$ Қазақ мал шаруашылығы жем өндірісі ғылыми-зертmеу институты, \\ Алматы, Қазақстан \\ ${ }^{2}$ Қазақ аграрлық-өнеркәсіптік кешенінің экономикасы және ауылдық аумақтарды \\ дамыту ғылыми-зерттеу институты, Алматы, Қазақстан \\ М.Б. КАЛМАГАМБЕТОВ ${ }^{1}$ \\ К.С.-Х.н., доцент \\ A.Н. КАРАБАEBA ${ }^{2}$ \\ магистр сельского хозяйства \\ ${ }^{1}$ Казахский научно-исследовательский институт животноводства \\ и кормопроизводства, Алматы, Казахстан \\ ${ }^{2}$ Казахский научно-исследовательский институт экономики АПК и развития сельских \\ территорий, Алматы, Казахстан
}

\begin{abstract}
The objectives of this study are to analyze the economic efficiency of using the method of artificial insemination of cows with semen divided by sex, ultrasound for diagnosing inseminated breeding stock livestock and diseases of reproductive function using the example of model dairy farms, which makes it possible to determine the development potential of these farms, to conduct an economic assessment of production level. Based on development materials, calculation of the effectiveness of model farms for production of milk and its processing products is presented, the possibilities of using new technologies for the automation of technological processes are shown. In the future, in research work on organization of similar model farms, an emphasis should be placed on the consideration of indicators reflecting the specifics of their functioning, as well as production and financial results of activities based on a systematic integrated approach. Currently, a significant acceleration of genetic progress in selection and breeding work is facilitated by the use of sex-separated or sexed sperm. In trials conducted in the USA on 211 farms, the fertility of Holstein heifers with sex-sperm reached $47 \%$, Jersey - $53 \%$. In the offspring, $89 \%$ of heifers were obtained. In Finland, insemination of cows with sexed sperm with 2 million sperm in a dose provided $20 \%$ of calving, as a result of which $82 \%$ of heifers were born, while during insemination with ordinary cryopreserved sperm (15 million sperm) - 45 and $49 \%$, respectively. The calculation proposed by the authors is based on identifying the percentage of live calves received from the number of cows and heifers of breeding age available on farms at the beginning of the analyzed year.
\end{abstract}




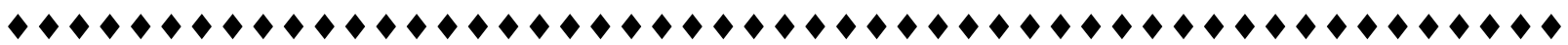

Аңдатпа. Бұл зерттеудің міндеттері - сиырларды жынысына қарай бөлінген тұқыммен жасанды ұрықтандыру әдісін қолданудың экономикалық тиімділігін талдау, ұрықтандырылған аналық мал басын және қалыптастырушы функцияның ауруын диагностикалау үшін ультрадыбыстық зерттеу, бұл осы фермалардың даму әлеуетін анықтауға, өндіріс деңгейіне экономикалық баға беруге мүмкіндік береді. Әзірлемелердің материалдары бойынша сүт және оны қайта өңдеу өнімдерін өндіру үшін модельдік шаруашылықтардың нәтижелілігін есептеу ұсынылған, Технологиялық процестерді автоматтандыру бойынша жаңа технологияларды пайдалану мүмкіндіктері көрсетілген. Бұдан әрі ұқсас модельдік фермаларды ұйымдастыру жөніндегі ғылыми-зерттеу жұмыстарында олардың жұмыс істеу ерекшелігін, сондай-ақ жүйелі кешенді тәсіл негізінде қызметтің өндірістік және қаржылық нәтижелерін көрсететін көрсеткіштерді қарауға баса назар аударған жөн. Қазіргі уақытта малды асылдандыру жұмысындағы генетикалық прогрестің едәуір жеделдеуіне жыныстық немесе жыныстық жолмен бөлінген ұрықты қолдану ықпал етеді. АҚШ-та 211 фермада жүргізілген сынақтарда Гольштейн сиырларының жыныстық ұрықпен ұрықтануы - 47\%, джерсей - 53\% жетті. Нәтижесінде 89\% бұзау алынды. Финляндияда сиырларды жыныстық шәуетпен 2 млн шәуетпен дозада ұрықтандыру төлдердің 20\%-ын қамтамасыз етті, соның нәтижесінде қашарлардың 82\%-ы туылды, ал кәдімгі криоконсервіленген шәуетпен (15 млн шәуетпен) ұрықтандыру кезінде тиісінше 45 және 49\%-ды құрады. Авторлар ұсынған есептеу талданатын жылдың басында шаруашылықтарда бар шағылыстыру жасындағы сиырлар мен қашарлар санынан алынған тірі бұзаулардың пайызын анықтауға негізделген.

Аннотация. Задачами данного исследования является анализ экономической эффективности применения способа искусственного осеменения коров семенем, разделенным по полу, УЗИ для диагностирования осемененного маточного поголовья и болезни воспроизводительной функции на примере модельных молочных ферм, что позволяет определить потенциал развития данных хозяйств, провести экономическую оценку уровня ведения производства. По материалам разработок представлен расчет результативности модельных хозяйств для производства молока и продуктов его переработки, показаны возможности использования новых технологий по автоматизации технологических процессов. В дальнейшем в научно-исследовательских работах по организации аналогичных модельных ферм следует сделать акцент на рассмотрение показателей, отражающих специфику их функционирования, а также производственные и финансовые результаты деятельности на базе системного комплексного подхода. В настоящее время значительному ускорению генетического прогресса в селекционно-племенной работе способствует использование разделённой по полу или сексированной спермы. В испытаниях, проведённых в США на 211 фермах, оплодотворяемость голштинских телок сексированной спермой достигала $47 \%$, джерсейских - 53\%. В потомстве было получено $89 \%$ телочек. В Финляндии осеменение коров сексированной спермой с 2 млн сперматозоидов в дозе обеспечило $20 \%$ отёлов, в результате которых родилось $82 \%$ тёлочек, в то время, как при осеменении обычной криоконсервированной спермой (15 млн сперматозоидов) - 45 и 49\%, соответственно. Расчет, предложенный авторами, основан на выявлении процента полученных живых телят от числа коров и телок случного возраста, имеющихся в хозяйствах на начало анализируемого года.

Key words: agriculture, dairy farming, breeding stock of cows, model dairy farms, production, milk, economic efficiency.

Түйінді сөздер: ауыл шаруашылығы, сүтті мал шаруашылығы, сиырлардың аналық басы, модельдік сүт фермалары, өндіріс, сүт, экономикалық тиімділік.

Ключевые слова: сельское хозяйство, молочное скотоводство, маточное поголовье коров, модельные молочные фермы, производство, молоко, экономическая эффективность.

Introduction. One of the priority areas of the AIC of Kazakhstan is livestock production development, especially dairy farming, the efficiency of which is largely determined by the state of reproduction of cattle herd. The high productivity of cows, capable of using nutrients for milk biosynthesis with maximum efficiency, is due to the intensity of metabolic processes and the intense functioning of all systems and organs [1].

In recent years, the process of introducing new technologies in this industry has intensified, but it should be noted that when using innovative technologies for milk production, animals are placed in harsh conditions, stress loads and predisposition to 


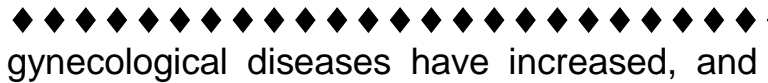
individual control over the state of reproduction function has become more complicated.

The increase in livestock production directly depends on stabilization of the cattle population in dairy farms, technologically justified raising of replacement young animals and growth of animal productivity. The system of these measures requires not only complete feeding and proper maintenance of cows, but also the use of a clear science-based system for monitoring and regulating reproductive function. So, to date, a significant acceleration of genetic progress in selection and breeding work is facilitated by the use of artificial insemination of cows with semen separated by sex [2].

In this regard, the necessity of assessing economic efficiency of using artificial insemination of cows with semen separated by sex and ultrasound for diagnosing inseminated breeding stock is justified based on the data from specific model dairy farms.

Material and methods of research. In conducting these studies, various methods of economic research were used: economicstatistical, abstract- logical, monographic, computational and constructive, etc.

In order to conduct an economic assessment of the effective use of the method of artificial insemination of cows with semen separated by sex, pregnancy of the inseminated breeding stock was determined and diseases of reproductive function were diagnosed using ultrasound. The calculation was based on identifying the percentage of live calves received from the number of cows and heifers of breeding age available on farms at the beginning of the analyzed year.

The calculation of economic efficiency of early pregnancy detection made it possible to reduce costs, since every day of infertility brings losses to the farm, resulting from the lost milk, lost calf and cost of keeping a barren cow.

The obtained results were processed and analyzed using financial and economic methodology, since economic effect, or financial component of the study, plays a significant role here. In the process of studying model farm that uses technologies aimed to automate technological processes in dairy production, to conduct more detailed determination of the advantages of new technology and economic effect of its implementation.

Moreover, calculation of the efficiency of milk production using advanced technologies is based on assessment of potential benefits from its sale, as a share of total sale effect, which is determined for each technology individually.

Results and their discussion. The experience of the achievements of developed countries in selection and breeding works confirms the high efficiency of using artificial insemination of cows with semen separated by sex or sexually sperm, and its significant impact on the acceleration of genetic progress. Thus, in trials conducted in the USA on 211 farms, the fertility of Holstein heifers with sexed sperm reached $47 \%$, Jersey heifers - 53\%, $89 \%$ of heifers were obtained in the offspring. In Finland, insemination of cows with sexed sperm with $2 \mathrm{mln}$ sperm in a dose provided $20 \%$ of calving, as a result of which $82 \%$ of heifers were born, while when inseminated with conventional cryopreserved sperm (15 mln sperm) - 45 and 49\%, respectively. Sexed semen, depending on technology of its production, guarantees the yield of 90 to $75 \%$ of calves of the required sex [see. 2].

Determining pregnancy -is an important economic component of a model dairy farm. There are several methods for diagnosing cow pregnancy: rectal, hormonal and ultrasonic. In rectal method, the specialist can identify pregnancy from the second month. Rectal examinations are safe from two months onwards, due to a rather high error rate. Hormonal, laboratory method - allows to determine pregnancy on 19-23 days after insemination. This method works well and is safe for the cows' health, but it takes more time compared to ultrasound diagnostics - one need to take milk samples or blood tests, make analysis, when determining the level of the hormone, it is important to consider that this method requires the creation of appropriate laboratory conditions, purchase of immune enzyme analyzer and monthly financial costs for consumables [see 2].

Ultrasound - diagnostics using an ultrasound scanner allows to make more accurate diagnoses at an earlier stage of 35-42 days, of course one can determine pregnancy on 2835 days after insemination, but there is a risk of embryonic mortality, in addition, scanners help to detect gynecological problems and diseases rather than traditional manual palpation starting from day 60 , as it is done in many farms. With the help of ultrasound diagnostics, it is also possible to determine the residual corpus luteum, which prevents ovulation of follicles (release of the egg cell), follicular and luteal cysts, hippofunction and a number of other gynecological diseases [3]. 
In addition, using ultrasound, it is possible, without knowing the date of insemination, to determine the age of fetus, which will allow to launch the animal in a timely manner and properly prepare for calving, which will allow the cow to recover faster after calving, reach the peak of productivity and become pregnant earlier.

One of the advantages of ultrasound diagnostics of pregnancy is also the speed of work - an experienced specialist spends from 30 seconds to 1 minute per cow, while in rectal method it may take 3 - 5 minutes or more. Previously, a doctor could fill with rectal palpation, and with the help of ultrasound scanner he can see, which means he can make more competent diagnosis and prescribe correct treatment. For example, endometritis at the initial stage of inflammation cannot be palpated by hand, so this method will allow prescribing appropriate treatment at an early stage of the disease, checking the result of particular hormonal scheme, determining pregnancy at 35 days, and significantly shortening the service period [see 3].

In the course of the study, in order to conduct an economic assessment of the effective use of the method of artificial insemination of cows with sex separated semen, pregnancy of the inseminated breed stock was determined and diseases of reproductive function were diagnosed using ultrasound. The calculation was based on identifying the percentage of live calves received from the number of cows and heifers of breeding age available on farms at the beginning of the analyzed year. Calculation of economic efficiency of early pregnancy detection made it possible to reduce cost of keeping livestock (barren cow); every day of infertility brings losses to the farm, which result from not received milk (NR) or not received calf.

NR milk is calculated (in monetary terms) according to following formula [4]:

\section{Average milk yield $\mathrm{kg} /$ day $x$ cost of milk $\mathrm{kg} / \mathrm{tg}=\mathrm{NR}$ milk, $\mathrm{tg}$}

The cost of a calf born by dairy cows (NR calf) is determined by the formula:

$3.61 \times$ cost of $1 \mathrm{c}$ of milk $\mathrm{tg}=\mathrm{NR}$ calf, $\mathrm{tg}$.,

where 3.61 - the amount of milk that can be received due to feed used for obtaining a calf from dairy cows;

The cost of $1 \mathrm{c}$ of milk tg- the price of $1 \mathrm{c}$ of milk of basic fat content. So 1 day of infertility of a cow on dairy farm costs:
NR calf, tg. $/ 280=$

cost of 1 day of infertility, $\operatorname{tg} /$ day

The cost of keeping a barren cow mainly consists of the feed day cost. The feed day cost, in turn, consists of the cost of daily ration, as well as the cost of care and maintenance.

The loss per day from each barren cow is calculated using the following formula:

Feeding day cost, tg / day +

care and maintenance costs, tg / day + cost of 1 day of infertility, $\operatorname{tg} /$ day $=$

loss per day from each barren cow, tg / day

The use of ultrasound to diagnose pregnancy allows to determine the result of insemination a month earlier and either reinseminate or cull the animal. The service period is reduced by at least 30 days, that is, we begin to receive milk from the cow in the next lactation 30 days earlier.

The total loss from one barren cow for the entire reproductive cycle is calculated as follows [see. 4]:

$$
\begin{gathered}
30 \text { days } x \text { loss per day from } \\
\text { each barren cow tg / day = } \\
\text { total loss from one barren } \\
\text { for the entire reproductive cycle, } t g
\end{gathered}
$$

Thus, one can calculate the payback of ultrasound scanner for a certain period of time (month):

$$
\begin{gathered}
\text { Cost of ultrasound scanner, } t g \text { / } \\
\text { total costs of barren cows, tg. } x \\
12 \text { months = return of } \\
\text { ultrasound scanner, months }
\end{gathered}
$$

The above indicators were calculated on the basis of model dairy farms: IB "Karimov" [5], APC "Plemzavod Almaty" [6], LLP "Tastobe Agrofud" [7], IB "Sadykov" [8] Almaty region, LLP "Borte Milka"[9] Turkestan region, PF "E. Zaytenov"[10] East Kazakhstan region, LLP "Kakpatas-Kordai" [11] Zhambyl region.

To ensure technological rhythm of herd reproduction, it is necessary to receive monthly $9-10 \%$ of calving from the livestock of the farm (complex), to carry out $14-16 \%$ of inseminations at $55-60 \%$ fertility. For such a rhythm of reproduction, not only complete feeding and proper maintenance of cows are required, but also the use of a clear scientifically grounded system of control and regulation of reproductive function [12].

Thus, economic assessment of the effective application of the method of artificial insemination of cows with sexed semen 


\section{Экономический механизм хозяйствования}

turned out to be profitable and amounted to additional income: in IB "Karimov" - 3937 thous. tenge, LLP "Kakpatas-Kordai" - 2614 thous. tenge, APC "Plemzavod "Almaty"- 7151 thous. tenge, LLP "Tastobe Agrofood" - 3054 thous. tenge, IB "Sadykov" - 1949 thous. tenge, LLP "Borte Milka" - 3716 thous. tenge and PF "E. Zaytenov"- 4121.7 thous. tenge.

The calf yield per 100 heads averages 35.5 heads in seven farms, and the output of heifers per 100 fertile cows is 30.4 heads. At

the same time, cost of semen in the structure of prime cost of 1 calf: IB "Karimov" - 41304 tenge, LLP "Kakpatas-Kordai" - 29688 tenge, APC " Plemzavod "Almaty" - 41304 tenge, LLP "Tastobe Agrofud" - 10556 tenge, IB "Sadykov "- 32759 tenge, LLP " Borte Milka "17399 tenge and PF "E. Zaytenov"- 22782 tenge. The average annual milk yield for three lactations on average for all farms was $314501.6 \mathrm{~kg}$ (tables 1, 2).

Table 1 - Economic assessment of the effective application of the method of artificial insemination of cows with sex separated semen in the surveyed model dairy farms

\begin{tabular}{|l|c|c|c|}
\hline \multirow{2}{*}{ Idicator } & IB "Karimov" & $\begin{array}{c}\text { LLP "Kakpatas- } \\
\text { Kordai" } \\
\text { Sex semen }\end{array}$ & $\begin{array}{c}\text { APC " Plemzavod } \\
\text { "Almaty" }\end{array}$ \\
\cline { 2 - 4 } & \multicolumn{3}{|c|}{} \\
\hline Average cost of 1 dose, tg & 9500 & 9500 & 9500 \\
\hline Insemination costs per 100 heifers, tg. & 950000 & 950000 & 950000 \\
\hline Calf yield per 100 cows & 23 & 32 & 23 \\
\hline $\begin{array}{l}\text { Calves output per 100 fruitfully inseminated } \\
\text { cows, head. }\end{array}$ & 21 & 30 & 24 \\
\hline The cost of semen in cost structure of 1 calf, tg & 41304 & 29688 & 41304 \\
\hline Semen costs, thous, tenge & 867,4 & 890,6 & 991,3 \\
\hline Duration of use of animals, months (lactations) & 36 & 72 & 72 \\
\hline Milk yield on average per lactation, kg & 324000 & 223059 & 511920 \\
\hline Cost of milk sold, thous. tenge & 39852 & 26767,1 & 71668,8 \\
\hline $\begin{array}{l}\text { Cost of milk sold, thous. tenge including } \\
\text { semen cost }\end{array}$ & 38984,6 & 25876,5 & 70801,4 \\
\hline Additional income, thous. tenge & 3937 & 2614 & 7151 \\
\hline \multicolumn{2}{|l|}{ Note: Compiled by the authors based on researches } \\
\hline
\end{tabular}

Table 2 - Economic evaluation of the effective application of the method of artificial insemination of cows with semen separated by sex in the surveyed model dairy farms

\begin{tabular}{|l|c|c|c|c|}
\hline \multicolumn{1}{|c|}{ Indicator } & $\begin{array}{c}\text { LLP } \\
\text { "TASTOBE } \\
\text { AGROFOOD" }\end{array}$ & $\begin{array}{c}\text { IB } \\
\text { "SADYKOV" }\end{array}$ & $\begin{array}{c}\text { LLP "BORTE } \\
\text { MILKA" }\end{array}$ & $\begin{array}{c}\text { PF "E. } \\
\text { ZAYTENOV" }\end{array}$ \\
\cline { 2 - 5 } & \multicolumn{4}{|c|}{ Sexed semen } \\
\hline Average cost of 1 dose, tg & 9500 & 9500 & 9500 & 9500 \\
\hline Insemination costs per 100 heifers, tg. & 950000 & 950000 & 950000 & 950000 \\
\hline Calf yield per 100 cows & 90 & 29 & 54,6 & 41,7 \\
\hline $\begin{array}{l}\text { Calves output per 100 fruitfully } \\
\text { inseminated cows, head. }\end{array}$ & 45 & 24 & 51,3 & 20,3 \\
\hline $\begin{array}{l}\text { The cost of semen in cost structure of } \\
1 \text { calf, tg }\end{array}$ & 10556 & 32759 & 17399 & 22781,8 \\
\hline Semen costs, thous. tenge & 475 & 786,2 & 892,6 & 462,5 \\
\hline $\begin{array}{l}\text { Duration of use of animals, months } \\
\text { (lactations) }\end{array}$ & 36 & 72 & 36 & 72 \\
\hline Milk yield on average per lactation, kg & 255960 & 223200 & 314028 & 349344 \\
\hline Cost of milk sold, thous. tenge & 30715,2 & 20088 & 37683,4 & 41271,4 \\
\hline $\begin{array}{l}\text { Cost of milk sold, thous. tenge } \\
\text { including semen cost }\end{array}$ & 30240,2 & 19301,8 & 36790,8 & 40809 \\
\hline Additional income, thous. tenge & 3054 & 1949 & 3716 & 4121,7 \\
\hline \multicolumn{2}{|l|}{ Note: Compiled by the authors based on researches } \\
\hline
\end{tabular}


$\bullet \bullet$
As a result of the research, artificial insemination of cows with semen, separated by sex, of the American breeding bulls Welcome gervase-et 501ho10247-66757435 of the Prestige line was carried out, which are enhancers for such breeding characteristics as milk productivity, limb positioning, udder volume and calving ease. The age of heifers at the first insemination decreased from 15.0 months up to 14.3 months. Live weight of heifers at the first insemination is $392-410 \mathrm{~kg}$ and $412-415 \mathrm{~kg}$.
During the research, average reproductive capacity of cows was determined in seven surveyed model dairy farms in different periods of the year. For this, such indicators as duration of service period, fertility of cows after the first insemination, the number of stillborn calves, the number of aborted cows, barrenness of cows, calf yield per 100 cows, average live weight of calves, milk yield per head and the number of somatic cells in milk have been studied Indicator (table 3).

Table 3 - Average reproductive capacity of cows in the surveyed model dairy farms in different periods of the year

\begin{tabular}{|l|c|c|c|}
\hline \multicolumn{1}{|c|}{ Indicator } & Spring & Summer & Fall \\
\hline Service period duration, days & 142 & 150 & 145 \\
\hline Fertility of cows after the first insemination,\% & 40 & 47 & 42 \\
\hline The number of stillborn calves, \% & 2 & 1,5 & 1,1 \\
\hline Number of aborted cows, \% & 2,2 & 0,4 & 0,9 \\
\hline Barrenness of cows, \% & 2 & 1 & 2,5 \\
\hline Calf yield per 100 cows, \% & 82 & 70 & 73 \\
\hline Average live weight of calves (at birth), $\mathrm{kg}$ & $34 \pm 0,41$ & $34 \pm 0,46$ & $33 \pm 0,26$ \\
\hline Milk yield per head, $\mathrm{kg}$ & $235 \pm 7,4$ & $220 \pm 6,8$ & $450 \pm 9,0$ \\
\hline Somatic cells, thousand / ml & $209 \pm 4,2$ & $292 \pm 4,8$ & $188,6 \pm 3,8$ \\
\hline Note: compiled by the authors based on researches
\end{tabular}

Ultrasound scanners are attractive for farms, first of all, due to the possibility of early detection of pregnancy, when economic component becomes priority. The traditional rectal method allows to determine pregnancy from day 60 , and when using ultrasound from day 35. If during rectal examination on day 60 after insemination the animal was not detected in heat and was not inseminated during 2.5 subsequent cycles (cycle $=21$ days) and remained not pregnant, then the duration of pregnancy determination will be 52.5 days.

When using ultrasound, the pregnancy of cows is determined 35 days after insemi- nation, if the animal was not detected in heat and was not inseminated within 1.5 subsequent cycles and remained not pregnant, then duration of determining pregnancy will be 31.5 days [see. 12].

A comparative analysis of the economic efficiency of using ultrasound scanner with traditional rectal method is presented in Table 4. The cost per 1 head per cycle when using ultrasound scanner amounted to 51345 tenge, costs when using traditional rectal method - 85575 tenge, the difference was 34 230 tenge per cycle, which confirms the greatest economic efficiency.

Table 4 - Comparative analysis of the economic efficiency of using ultrasound scanner and rectal traditional method

\begin{tabular}{|l|c|c|}
\hline \multicolumn{1}{|c|}{ Name } & Rectal method & Ultrasound scanner \\
\hline Costs of keeping non-fertile cow head / day, tenge & 1630 & 1630 \\
\hline Cycle & 2,5 & 1,5 \\
\hline Days & 52,5 & 31,5 \\
\hline Total costs 1 goal / cycle, tenge & 85575 & 51345 \\
\hline Note: compiled by the authors based on research \\
\hline
\end{tabular}

The analysis of economic efficiency of using ultrasound for diagnosing inseminated breeding stock in model dairy farms showed that, if the possibility of fertilization of a cow was not missed, the loss from each barren cow was as follows: in IB "Karimov" - 3,419tg, LLP "Kakpatas-Kordai" - 3,355 tenge; APC "Plemzavod Almaty" - 3423 tenge, LLP "Tastobe Agrofud" - 3395 tenge, IB "Sadykov" - 3 


\section{Экономический механизм хозяйствования}

246 tenge, LLP "Borte Milka" - 3408 tenge and PF "E. Zaytenov "- 3392 tenge per day.

The calculation of economic efficiency of early detection of pregnancy shows cost reduction resulting from the lost milk: in IB "Karimov" - 2850 tenge, LLP "KakpatasKorday" - 900 tenge, APC "Plemzavod "Almaty"- 1948 tenge, LLP "Tastobe Agrofud"2,163 tenge, IB "Sadykov"- 622 tenge, LLP
"Borte Milka"- 3,024 tenge and PF "E. Zaytenov"- 1283 tenge per day, the lost calf on average in seven farms - 43747.7 tenge.

Thus, the cost of keeping barren cows for the entire reproductive cycle averaged 101.3 thousand tenge per head of cattle, the cost of keeping barren cows on average for seven surveyed farms amounted to 1162.7 thousand tenge (tables 5.6).

Table 5 - Calculation of the economic efficiency of early detection of pregnancy using ultrasound scanner in 7 model dairy farms

\begin{tabular}{|c|c|c|c|}
\hline \multirow[t]{2}{*}{ Indicator } & IB "KARIMOV" & $\begin{array}{c}\text { LLP } \\
\text { "KAKPATAS - } \\
\text { KORDAY" }\end{array}$ & $\begin{array}{c}\text { APC } \\
\text { "PLEMZAVOD" } \\
\text { ALMATY" }\end{array}$ \\
\hline & \multicolumn{3}{|c|}{ Sexed semen } \\
\hline Cost of an ultrasound scanner, tenge & 1000080 & 1000080 & 3000000 \\
\hline Number of cows, heads & 400 & 194 & 1522 \\
\hline Cost of $1 \mathrm{~kg} / \mathrm{tg}$ of milk & 95 & 60 & 95 \\
\hline Cost of $1 \mathrm{~kg} / \mathrm{tg}$ of milk & 123 & 120 & 142 \\
\hline Not received milk, $\operatorname{tg}$ / day & 2850 & 900 & 1948 \\
\hline Not received calf, tg & 44403 & 43320 & 51262 \\
\hline Loss per day from each dry cow, tg / day & 3419 & 3355 & 3423 \\
\hline $\begin{array}{l}\text { Total loss from one barren animal for the } \\
\text { entire reproductive cycle, tenge }\end{array}$ & 102557 & 100641 & 102692 \\
\hline Number of identified cows, heads & 8 & 4 & 30 \\
\hline Total costs of barren cows, tenge & 820460 & 390489 & 3129487 \\
\hline Payback of ultrasound scanner, month & 15 & 31 & 12 \\
\hline
\end{tabular}

Table 6 - Calculation of the economic efficiency of early detection of pregnancy using ultrasound scanner in 7 model dairy farms

\begin{tabular}{|c|c|c|c|c|}
\hline \multirow[t]{2}{*}{ Indicator } & $\begin{array}{c}\text { LLP } \\
\text { "TASTOBE } \\
\text { AGROFOOD" }\end{array}$ & $\begin{array}{c}\text { IB } \\
\text { "SADYKOV" }\end{array}$ & $\begin{array}{c}\text { LLP } \\
\text { "BORTE } \\
\text { MILKA" }\end{array}$ & $\begin{array}{l}\text { PF "E. } \\
\text { ZAYTENOV" }\end{array}$ \\
\hline & \multicolumn{4}{|c|}{ Sexed semen } \\
\hline Cost of an ultrasound scanner, tenge & 3000000 & 3000000 & 3000000 & 3000000 \\
\hline Number of cows, heads & 629 & 172 & 470 & 600 \\
\hline Cost of $1 \mathrm{~kg} / \mathrm{tg}$ of milk & 103 & 61 & 105 & 95 \\
\hline Cost of $1 \mathrm{~kg} / \mathrm{tg}$ of milk & 120 & 90 & 130 & 118 \\
\hline Not received milk, $\operatorname{tg} /$ day & 2163 & 622 & 3024 & 1283 \\
\hline Not received calf, tg & 43320 & 32490 & 46930 & 42598 \\
\hline Loss per day from each dry cow, tg / day & 3395 & 3246 & 3408 & 3392 \\
\hline $\begin{array}{l}\text { Total loss from one barren animal for the } \\
\text { entire reproductive cycle, tenge }\end{array}$ & 101841 & 97381 & 102228 & 101764 \\
\hline Number of identified cows, heads & 13 & 3 & 9 & 12 \\
\hline Total costs of barren cows, tenge & 1281165 & 334991 & 960945 & 1221169 \\
\hline Payback of ultrasound scanner, month & 28 & 107 & 37 & 29 \\
\hline
\end{tabular}

\section{Conclusion.}

1. The analysis of economic efficiency of using the method of artificial insemination of cows with semen separated by sex and ultrasound for diagnosing the inseminated breeding stock and reproductive function diseases on the basis of seven surveyed model dairy farms made it possible to determine the development potential of these farms, to conduct an economic assessment of production level.

2. The economic assessment of the effective application of the method of artificial insemination of cows with sexed semen turned out to be profitable and allowed the farms to receive additional income: in IB 
"Karimov" - 3937 thous. tenge, LLP "Kakpatas-Kordai" - 2614 thous. tenge, APC "Plemzavod "Almaty" - 7151 thous. tenge, LLP "Tastobe Agrofood" - 3054 thous. tenge, IP "Sadykov" - 1949 thous. tenge, LLP "Borte Milka" - 3716 thous. tenge and PF "E. Zaytenov "- 4121.7 thous. tenge.

3. Calculation of the economic efficiency of early pregnancy detection made it possible to reduce costs resulting from the lost milk: at the IP Karimov - 2850 tenge, LLP "KakpatasKordai" - 900 tenge, SPK "Plemzavod" Almaty "- 1948 tenge, LLP " Tastobe Agrofood "2163 tenge, IB "Sadykov"- 622 tenge, LLP " Borte Milka "- 3024 tenge and PF " E. Zaytenov "- 1283 tenge per day.

4. Thus, in the course of the study, main advantages of ultrasound examination were revealed, which make it possible to more accurately make diagnosis, prescribe appropriate treatment, check the result of particular hormonal scheme, determine pregnancy within 30 days, and significantly reduce the service period. The advantage of ultrasound diagnostics in comparison with rectal and laboratory methods is undeniable. For a long time, this type of diagnostics was not available due to the lack of devices or their high cost, at the moment, if reliable devices are available at affordable price, they are quite actively used in farms and quickly pay off.

\section{References}

1 Akimbekova, G.U. The current state of dairy cattle breeding in model farms of Almaty region / G.U. Akimbekova., A.B. Baimukhanov, U.R. Kaskabaev // Problems of the agricultural market. -2019.- No. 4.-P. 11-19.

2 Kurdeko, A. P. Directed growing of replacement young animals / A. P. Kurdeko, N. A. Popkov, V. N. Timoshenko et al. - Gorki: BSKhA, 2011. - 88p.

3 Babkin, A.V. The importance of early pregnancy diagnosis using an ultrasound scanner [Electronic resource].- 2017.-URL: http: // www. prok.ru/info/articles/znachenie-ranneydiagnostiki-stelnosti-s-pomoshchyu-uzi-skanera/ (date of access: 02.09.2020).

4 Breeding of farm animals: guidelines for the study of the discipline and assignments of control work and a course project for correspondence students with. universities. Gorki: BSKhA, 2018. - 82p.

5 Materials of primary accounting of the model farm of IB "Karimov" of Koksuy district of Almaty region. Department of agriculture of Almaty region.-Taldykorgan, 2019.- $32 \mathrm{p}$.

6 Materials of primary accounting of the model economy of the APC "PZ " Almaty " in Talgar district of Almaty region. Department of agriculture of Almaty region. -Taldykorgan, 2019.- $42 \mathrm{p}$.

7 Materials of primary accounting of the model economy of LLP "Tastobe AgroFood", Karatal district, Almaty region. Department of agriculture of Almaty region. - Taldykorgan, 2019. - 46 p.

8 Materials of primary accounting of the model farm of IP "Sadykov" Talgar district of Almaty region. Department of agriculture of the Almaty region.-Taldykorgan, 2019.- $41 \mathrm{p}$.

9 Materials of primary accounting of the model farm "Borte Milka" LLP, Ordabasy district, Turkestan region. Department of Agriculture of Turkestan region. - Turkestan, 2019. - $55 \mathrm{p}$.

10 Materials of primary accounting of the model farm PF "Zaytenov" Borodulikha district of the East Kazakhstan region. Department of Agriculture of the East Kazakhstan region.- UstKamenogorsk, 2019.- 47 p.

11 Materials of primary accounting of the model economy of "Kakpaktas-Kordai" LLP, Kordai district of the Zhambyl region. Department of Agriculture of the Zhambyl region, Taraz, 2019, $54 \mathrm{p}$.

12 R.G. Kuzmich. Organization of cattle reproduction: methodological guide / R.G. Kuzmich [and others]. - Vitebsk: VGAVM, 2012.- 44.

Information about authors:

Kalmagambetov Murat Baitegulovich, Candidate of Agricultural Sciences, Associated Professor, LLP "Kazakh Scientific Research Institute of Animal Husbandry and Forage Production", Almaty, Kazakhstan, mbaitugel@mail.ru, https://orcid.org/0000-0003-0675

Aizhan Karabayeva, Master of Agriculture, Head of the Sector Specialization of Agricultural Formations, Kazakh Research Institute of Economy of Agro-Industrial Complex and Development Rural, Almaty, Kazakhstan, aikarabaeva@gmail.com, https://orcid.org/0000-0002-3405-132X 